\title{
How Effective Are Second-Generation Road Funds? A Preliminary Appraisal
}

\author{
Ken Gwilliam • Ajay Kumar
}

Underfunded, inefficient road maintenance is a perennial problem in many developing economies. To address it, some countries have created "second-generation" road funds that are financed by fuel levies and managed by boards representing the interests of road users. Macroeconomists often oppose such funds, arguing that this earmarking of revenue reduces fiscal flexibility. Some argue that such road funds should be seen as an interim step toward fully commercialized road maintenance or good public sector governance-and hence subject to sunset provisions. Decisions on whether to retain (or create) such funds should then be based on their effects on resource allocation, operational efficiency, and rent seeking. Using evidence on new road funds in Africa, this article finds that they have not undermined fiscal flexibility. Moreover, they have improved the administration of road funding (in terms of execution capability) and its outputs (in terms of road conditions). So, although criteria for assessing road funds remain relevant, the funds should not automatically be considered temporary mechanisms. But when establishing new funds, government's continued role in approving spending on road maintenance should be explicitly recognized.

Studies of road systems in developing economies over the past two decades have consistently shown that road maintenance is underfunded-as demonstrated by very high returns to investments in maintenance and rehabilitation. But maintenance is often inefficient - as evidenced by low productivity in the implementation of works that receive funding (Harral and Faiz 1988). Many countries have addressed underfunding by earmarking specific tax revenues to road funds. But this approach has traditionally been opposed by macroeconomists, both in the International Monetary Fund and the World Bank, because it undermines governments' fiscal flexibility (Potter 1997).

In response to this opposition, over the past decade more than 20 countries have introduced a new model of road fund. Under these so-called second-generation road funds, fuel taxes include both general revenue taxes and road user charges. Govern-

The World Bank Research Observer, vol. 18, no. 1 (Spring 2003), pp. 113-128 
ments set the general revenue taxes, and (in theory) road boards-with significant user representation - determine the road user charges and control the revenue from them (Heggie 1995). Separate agencies are responsible for actual road maintenance. This approach is supposed to reduce rent seeking and make resource allocation more efficient by creating an explicit link between what users pay for roads and the quality of the roads available to them.

Gwilliam and Shalizi (1999) highlighted the tension between the traditional macroeconomist approach — which tends to presume that good governance exists - and the sector specialist approach, which is based on the perception that it does not. The authors concluded that road funds should be seen as a step toward either establishing good governance in the allocation of public revenue or the general commercialization of road use. Thus road funds should be subject to sunset provisions and assessed on a case-by-case basis using objective indicators of their effects (or likely effects) on resource allocation efficiency, operational efficiency, and rent-seeking behavior.

But such assessments are not easy because there is never a right time for a definitive appraisal. It can always be argued that it is too early to make a judgment, because effects are likely to develop over a long period, or that it is too late, because too much has changed in the ambient circumstances to identify cause and effect. This problem is compounded by the difficulty of establishing a secure counterfactual. Still, that is no excuse for avoiding the challenge.

Architects of second-generation road funds argue that specific changes in the structure of road maintenance financing make it possible to introduce better business processes, with benefits for performance. This article is based on detailed reviews of experiences in seven African countries where the World Bank has been involved in establishing second-generation road funds (Kumar 2000a) and one (Uganda) where the government sought to improve road performance but rejected arguments for a road fund (Kumar 2002a,b). Although the road funds analyzed are of different ages, common indicators of structure, process, and performance make it possible to examine the effectiveness of the new approach and consider its implications for future road funds.

\section{Road Fund Structures}

The boards that direct the use of these second-generation road funds are designed to be autonomous agencies that — directed primarily by road users - have the power to raise and allocate revenue for road maintenance. These boards have a strong incentive to insist on professional, cost-effective management of such works but are not intended to execute them: such tasks are normally performed by national or regional road agencies or by private contractors that submit financing proposals to the road fund's board. Structural indicators for the road funds assessed in this article include the strength of their legal basis; the size, composition, and chairmanship of their 
managing boards; the duties and powers attributed to the boards; and the provisions to ensure the technical competence of their permanent staff (table 1).

Although all of the second-generation road fund boards have a secure legal basis, most have not been as independent from government or possessed the full range of powers envisaged by their proponents.

\section{Legal Basis and Functions}

The legal basis of the road funds and boards is generally secure, with all except Zambia's established by Parliament. Even in Zambia, the fact that the road fund was established by regulation under an existing ministerial order does not appear to have affected its authority or effectiveness.

The roles of the road fund boards vary. Most serve as financiers rather than providers of services, with the programming, tendering, evaluating, negotiating, awarding, supervising, and managing of contracts generally being the responsibilities of the road agencies to whom funds are allocated. But there are exceptions. Zambia's board advises road agencies on procurement, monitors performance under the national road investment plan, and coordinates donor-financed programs-including management of the 10-year road investment program. Malawi's National Road Administration is still a road implementation agency, though ultimately it is intended to separate implementation staff in an independent Central Roads Authority. Several boards advise on general road policy matters, such as vehicle overloading.

\section{Resource Powers}

In principle, all the African road fund boards are responsible for generating and allocating resources for road maintenance. But in practice, the boards' resource powers are much more restricted than originally envisaged. None of the boards is able to set the fuel levy; in most cases spending programs must be approved by one or more government ministries.

For example, Benin's road board is required to implement the policies set by the Review Council, a body consisting of one government and two donor representatives. Only Malawi's board has the formal power to determine the levy, though in practice it always seeks the approval of the minister of transport and public works and the minister of finance.

\section{Composition of Boards and Professional Base}

The composition of the road fund boards differs significantly across countries. In Ghana, Kenya, Malawi, and Zambia the boards are dominated by private sector representatives. But in Benin and Ethiopia the boards are dominated by the public sec- 


\begin{tabular}{|c|c|c|c|c|c|c|c|c|}
\hline Indicator & Benin & Ethiopia & Ghana & Kenya & Malawi & Tanzania & Zambia & Uganda $^{a}$ \\
\hline Year created & 1996 & 1997 & 1997 & 2000 & 1998 & 1999 & 1994 & n.a. \\
\hline Legal basis & Law & Law & Law & Law & Law & Law & $\begin{array}{l}\text { Ministerial } \\
\text { order }\end{array}$ & n.a. \\
\hline $\begin{array}{l}\text { Number of private sector members } \\
\text { on board }\end{array}$ & 5 of 9 & 4 of 15 & 8 of 13 & 8 of 13 & 9 of 12 & 5 of 9 & 7 of 11 & n.a. \\
\hline Board chair & $\begin{array}{l}\text { Minister } \\
\text { of works }\end{array}$ & $\begin{array}{l}\text { Minister } \\
\text { of works }\end{array}$ & $\begin{array}{l}\text { Minister } \\
\text { of works }\end{array}$ & $\begin{array}{l}\text { Private } \\
\text { actor }\end{array}$ & $\begin{array}{l}\text { Private } \\
\text { actor }\end{array}$ & $\begin{array}{l}\text { Former } \\
\text { permanent } \\
\text { secretary, } \\
\text { Ministry of } \\
\text { Finance }\end{array}$ & $\begin{array}{l}\text { Private } \\
\text { actor }\end{array}$ & n.a. \\
\hline Is planning separate from execution? & Yes & Yes & Yes & Yes & No & Yes & Yes & Yes \\
\hline Does the board set the fuel levy? & No & No & No & No & No & No & No & n.a. \\
\hline Does the board propose the fuel levy? & Yes & No & No & Yes & Yes $^{b}$ & No & Yes & n.a. \\
\hline Is management professional? & Partly & Yes & Yes & In process & Yes & Yes & Yes & Yes \\
\hline Does the board have additional functions? & No & No & No & No & Yes & No & Yes & n.a. \\
\hline $\begin{array}{l}\text { Have semi- or independent executing } \\
\text { agencies been established? }\end{array}$ & No & No & No & No & Partly & Yes & No & Yes \\
\hline
\end{tabular}

\section{n.a., not applicable.}

${ }^{a}$ Uganda opted not to create a road fund. Instead, road maintenance requirements are met through the normal budget process.

bIn practice the National Road Administration always seeks ministerial approval.

Source: World Bank data. 
tor (including regional representatives in Ethiopia). In both countries and in Ghana, the minister of works is the chairperson of the board. Elsewhere the chair is appointed by the minister but is not from the public sector (Kenya, Malawi) or is chosen by the board from among its private sector members (Zambia). In Tanzania the chair is appointed by the president from candidates outside the civil service.

The professional base for each road fund board is its secretariat, which performs its day-to-day functions. The size of the secretariat ranges from 3 members in Benin to 13 in Ghana. Secretariats' administrative and operating expenses are usually paid from the road funds and average about 3 percent of their collections - except in Ethiopia, where administrative expenses are allocated by the Ministry of Finance and equal less than 1 percent of the fund's collections. In most of the countries assessed, salaries for secretariat workers are competitive with those in the private sector. Where they are not, as in Ethiopia and Kenya, it is extremely difficult to attract qualified staff. After two years of existence the Ethiopia road fund secretariat had filled less than 30 percent of designated professional positions.

\section{Role of Executing Agencies}

Effective executing agencies are essential to road sector reform. Lack of executing capability is the main reason for poor road maintenance, particularly for regional and rural roads. Although road works are increasingly contracted to private firms, SubSaharan governments are reluctant to delegate road management to autonomous agencies operating according to sound business practices (Nyangaga 2001). In most countries with a road fund, main roads are managed by a roads department within a ministry of works. Most of the statutes founding road funds do not provide for institutional reform of executing agencies. In contrast, a core part of Uganda's reform was the creation of an independent engineering organization to procure resources from the market through competitive tendering.

\section{Uganda: Reforming without a Road Fund}

Other elements of Uganda's alternative approach are also worth mentioning. In 1995 the government introduced a Road Sector Development Plan to shift its involvement from direct provision of services to provision of policy guidelines and a clear legal framework for implementation of works (Kumar 2002a). The plan included commercializing and contracting technical services on a performance basis under hard budget conditions, separating planning and financing from procurement and implementation, and decentralizing maintenance delivery on district, urban, and community roads.

But the plan did not provide for an autonomous road board; policy and regulation continued to be the responsibility of the Ministry of Works, Housing, and Communications. Although the plan committed to providing stable and secure funding for road 
maintenance, maintenance was left on budget. The ministry's weakness in implementation was addressed by the plan's provision for an autonomous Road Agency, preceded during its formation by a Road Agency Formation Unit responsible to the ministry. This reform is not complete. The unit acts as a professional procurement agency, focusing on rehabilitation and reconstruction rather than maintenance, with heavy external financial and technical support. It remains to be seen how it will perform as a maintenance-focused roads agency.

\section{Road Fund Processes}

The concept of second-generation road funds is as concerned about process as structure. The funds are designed to develop businesslike (rather than bureaucratic) processes to provide adequate, stable financing for road maintenance. The aim is to develop a new strategy for maintenance, focused on outsourcing most work in a commercial environment.

This approach requires developing performance-based, long-term maintenance contracts managed by professional staff. These arrangements are intended to cut the huge overhead costs associated with maintaining large road agencies and to encourage local contractors to invest in equipment. The process indicators derived from this approach include the ways that revenue and spending totals are set, funds are transferred and secured, revenue is allocated, and implementation (by both road boards and executing agencies) is monitored and audited (table 2).

Overall, funding arrangements have become more transparent, with financial audits working well in most countries. Although delays still occur, transfers of approved revenue to road accounts are more secure. Similarly, though formal allocation procedures are still not well developed and technical auditing remains limited, arrangements have improved since road funds were established. The capacity and effectiveness of implementing agencies have developed least rapidly, though again there has been progress, particularly among private contractors. The income of road funds remains largely under government control, however, rather than being determined by road boards.

\section{Processes for Determining Revenue}

In all the countries examined (except Ethiopia) fuel levies are the main source of revenue for road funds. In Benin and Zambia the fuel levy is a fixed percentage of the wholesale price, whereas in Ethiopia, Ghana, and Tanzania its is a fixed charge per liter. The danger of setting the fuel levy as a percentage of the fuel price is that collections may have no relation to maintenance needs, and road fund revenues may fluctuate with changes in the macroeconomic environment. 


\begin{tabular}{|c|c|c|c|c|c|c|c|c|}
\hline Indicator & Benin & Ethiopia & Ghana & Kenya & Malawi & Tanzania & Zambia & Uganda $^{a}$ \\
\hline $\begin{array}{l}\text { Are fuel levies paid } \\
\text { directly to the road fund? }\end{array}$ & No & Yes & No & Yes & Yes & No & No & n.a. \\
\hline $\begin{array}{l}\text { What percentage of the fund's } \\
\text { revenue comes from the fuel levy? }\end{array}$ & 75 & 25 & 85 & $>90$ & 95 & 95 & 95 & n.a. \\
\hline $\begin{array}{l}\text { What percentage of revenue comes } \\
\text { from other earmarked duties and fees? }\end{array}$ & 10 & 75 & 0 & $<10$ & 5 & 0 & 0 & n.a. \\
\hline Are funds transferred each month? & Yes & Yes & Yes & Yes & Yes & No & No & Yes \\
\hline $\begin{array}{l}\text { Are independent technical } \\
\text { audits performed? }\end{array}$ & No & In process & Yes & $\mathrm{No}^{\mathrm{b}}$ & No & Yes & No & In process \\
\hline $\begin{array}{l}\text { Are independent financial audits } \\
\text { performed? }\end{array}$ & No & In process & Yes & $\mathrm{No}^{\mathrm{b}}$ & Yes & Yes & Yes & In process \\
\hline $\begin{array}{l}\text { Are there performance audits of } \\
\text { implementation and management? }\end{array}$ & No & Yes & Yes & No & No & No & No & Yes \\
\hline $\begin{array}{l}\text { Is there a program to empower small } \\
\text { and medium-size contractors? }\end{array}$ & Yes & Yes & Yes & Yes & Partly & Yes & Partly & In process \\
\hline What are the fund's objectives? & Maintenance & Maintenance & $\begin{array}{l}\text { Maintenance } \\
\text { \& rehabilitation }\end{array}$ & $\begin{array}{l}\text { Maintenance } \\
\text { \& repair }\end{array}$ & Maintenance & Maintenance & $\begin{array}{l}\text { Maintenance } \\
\& \text { rehabilitation }\end{array}$ & n.a. \\
\hline $\begin{array}{l}\text { n.a., not applicable. } \\
\text { aUganda opted not to create a road fund } \\
\text { bAudits have not been completed becau } \\
\text { Source: World Bank data. }\end{array}$ & $\begin{array}{l}\text { d. Instead, road } \\
\text { se the fund's sec }\end{array}$ & $\begin{array}{l}\text { aintenance req } \\
\text { tariat is new, } b\end{array}$ & $\begin{array}{l}\text { rements are me } \\
\text { t they are requir }\end{array}$ & $\begin{array}{l}\text { rough the no } \\
\text { by law. }\end{array}$ & budget pro & & & \\
\hline
\end{tabular}


Thus what matters most is how the fuel levy is assessed and adjusted. Ideally it should be based on assessed maintenance needs as well as the absorptive capacity of monitoring and executing agencies. In Zambia the road board operates on the basis of an annual works program based on road agencies' identified needs. Benin's road board negotiates the amount each year with the Ministry of Finance based on the road fund budget.

This approach appears to be consistent with the principle of incrementality- that the user charge element is in addition to what would have been levied for general tax purposes in its absence. But for countries with high fuel levies and those with neighbors (such as Nigeria) with low taxes, the price elasticity of demand for fuel might be high enough to ensure that any increase in the fuel levy would reduce its yield even if its nominal level was unchanged. Recognizing this, governments have generally insisted on retaining effective control over the user charge levy as well as the basic fuel levy. In Ethiopia about 75 percent of road fund revenue comes from the sales tax and a municipal fuel levy; in all the other countries fuel levies occur at the national level.

Though the introduction of a fuel levy is a big step forward, it remains a proxy (indirect) charge for road use. Arrangements to diversify road user charges, including through direct charges for road use, are being explored. For example, Benin's road fund gets 10 percent of its revenue from tolls and weight controls deposited directly into its account by the toll concessionaire. Zambia's road board has sought additional funds through international transit tolls, fines for excess weight on bridges, and motor vehicle license fees.

\section{Processes for Securing Income}

In principle, one of the main advantages of creating a road fund is that user charges provide a link between the level and quality of service and the price paid for it. But in practice, governments are reluctant to relinquish control over cash flows and the opportunity to "borrow" funds for other purposes if the need arises (Nyangaga 2001). In Kenya payments are made from the customs department to the Ministry of Public Works and Highways and then to the road fund. In Benin and Zambia the fuel levy is channeled to the road fund from the Petroleum Commission through the Ministry of Finance, creating delays of four months and two months, respectively.

The interposition of a ministry of works or finance in the process is also likely to generate leakages. For example, in Zambia in 1999 only about two-thirds of the fuel levy delivered to the National Revenue Authority by the National Oil Authority found its way to the road fund. In Tanzania the fuel levy is collected by the Tanzania Revenue Authority in the Dar es Salaam region and deposited in a Ministry of Finance account. From there the money is passed on to the Ministry of Works (for main roads) and the Ministry of Local Government (for district roads). These amounts are then 
transferred to the road fund, which is responsible for disbursements to executing agencies. The collection process from up-country regions involves even more steps. Between 1996 and 1999 these complicated mechanisms caused a two-month delay and 25 percent leakage in the original levy (Kumar 2002b).

\section{Monitoring Performance}

Second-generation road funds should arrange for independent monitoring of the flow of funds and of the quantity, quality, and cost of road projects. Available evidence shows mixed results in this regard. Zambia's road fund accounts are prepared quarterly and audited by an independent external auditor. But they are prepared without any explanation of how funds are used and leave a number of questions unanswered. Ethiopia has introduced procedures to monitor the performance of the national roads agency (the Ethiopian Road Authority), but weaker regional and urban authorities have a long way to go before performance-based systems can be established. Currently they are required to report only on how funds are used. In contrast, Ghana's road fund board has established proper planning and programming of road works along with welldefined disbursement and accounting procedures, facilitating timely contracting arrangements.

\section{Technical Auditing}

To improve performance, technical auditing should continuously audit projects under way. To do so, countries must:

- Establish a credible, independent external auditing process to monitor the quantity and quality of work and ensure transparency and accountability in the use of road maintenance funds.

- Establish appropriate responsibilities for reporting and following up on audit recommendations to ensure their effectiveness.

- Develop an updated inventory and condition survey of the classified road network.

Most of the countries studied lack systematic arrangements for independent technical audits. A remarkable exception is Ghana, which has detailed internal and external monitoring procedures to ensure efficient use of money, accompanied by monthly progress reports and external financial and technical audits.

\section{Formal Allocation Processes}

Given their commercial orientation and strong constituencies, second-generation road funds should in principle be able to allocate resources for road maintenance 
efficiently. But in practice resource allocations continue to be driven by standard formulas rather than by planned reviews of programs put forward by road administrations - especially in Benin, Ethiopia, Kenya, and Zambia. In Kenya 40 percent of road fund revenues are allocated to constituencies and districts for lower category road maintenance, and 57 percent goes to the roads department for the main road network.

Disbursements appear to be biased toward urban and main roads, to the detriment of the rural and feeder roads. In Kenya and Zambia road maintenance resources have been diverted to rehabilitate roads in the nations' capitals, reflecting their high political profile and the fact that the most ardent supporters of the road funds are car-owning urban residents. In addition, in several countries spending planned for rural roads is poorly disbursed, primarily because of lack of capacity at the regional level. In Ethiopia only about 20 percent of the planned allocations for rural roads were disbursed in fiscal year 1999 because of a lack of absorptive capacity. In Tanzania less than 40 percent of programmed works for district roads were undertaken in fiscal 2001.

\section{Development of Supply Agencies}

Developing supply agencies is essential to ensure that road executing agencies use allocated resources effectively and efficiently. Available evidence in this area offers mixed results. Although some countries have set up semi-autonomous road agencies (Tanzania, Uganda), siphoning off executing and service delivery functions from the ministry of works, others (Ghana, Kenya, Zambia) have tried to reform existing government departments. Malawi has combined road financing and road executing functions in the same agency. In general, these agencies lack a commercial orientation and have continued to work as government departments without clear objectives, functions, or work programs. In addition, reporting arrangements between regional offices and headquarters are weak. The capacity of district road agencies raises even greater concern.

\section{Performance Outcomes}

Reliable, comprehensive data on performance outcomes are sparse. Even in Ghana, where the government hired consultants to audit all funding related to the Highway Sector Investment Program, the audit did not report on the share of planned programs executed, address the relationship between the amount of money allocated for maintenance and the quality of the work, or fully assess spending management, control, and effectiveness.

Besides being incomplete, evidence on performance remains somewhat anecdotal. Still, some indicators are available, including trends in allocations and disbursements, implementation efficiency, and the ultimate outcomes of road conditions (table 3). 
Table 3. Performance Indicators for Road Funds in Various Countries

\begin{tabular}{|c|c|c|c|c|c|c|c|c|}
\hline Indicator & Benin & Ethiopia & Ghana & Kenya & Malawi & Tanzania & Zambia & Uganda \\
\hline Administrative expenses/income & 2 & $>1$ & 3 & 3 & $<3$ & 1 & $<3$ & \\
\hline Annual change in roads in good condition & 9 & 3 & 5 & & & & 4 & \\
\hline Annual change in roads in bad condition & & -10 & $>-10$ & & $>-10$ & & -6 & \\
\hline $\begin{array}{l}\text { Annual change in maintenance works } \\
\text { contracted out }\end{array}$ & & 10 & 30 & & 30 & $>30$ & $>30$ & 10 \\
\hline Share of needed maintenance financed & & 75 & 50 & $>70$ & 30 & 30 & 30 & 80 \\
\hline $\begin{array}{l}\text { Breakdown of allocated funds } \\
\text { (trunk/urban/rural roads) }\end{array}$ & & & $52 / 27 / 20$ & & $48 / 42 / 10$ & $70 / 30^{\mathrm{a}}$ & $40 / 20 / 40$ & \\
\hline $\begin{array}{l}\text { Share of allocated funds disbursed } \\
\text { (trunk/urban/rural roads) }\end{array}$ & 55 (average) & $65 / 55 / 20$ & & $50 / 40 / 2$ & & $100 / 50^{\mathrm{a}}$ & $24 / 69 / 8$ & \\
\hline
\end{tabular}

(trunk/urban/rural roads)

Note: The rates of change in the table do not all cover the same period, but instead reflect the average annual rate of change since the road funds were created (see table 1 for the years the funds were created). In the absence of detailed road inventories in most countries, it is difficult to determine the percentage change in the quality of the road network, which explains the many blank cells. In addition, heavy donor investments in rehabilitation and reconstruction of paved roads have significantly improved road quality, making it difficult to isolate the impact of better maintenance funding.

aFunds allocated only between two agencies, the first responsible for trunk roads and the second for urban and rural roads.

Source: World Bank data. 
Overall, although underfunding of road maintenance has been reduced, it remains a serious problem. Similarly, though contractors have become better able to absorb allocated funds, several countries still suffer from inadequate capacity of maintenance providers. Despite these limitations, maintenance costs have been reduced, and longterm declines in road quality have been arrested and in some countries significantly reversed.

\section{Underfunding}

Funding for maintenance has increased in all the countries reviewed, though in most the amounts still fall far short of what is needed. Revenue accruing to Zambia's road fund is sufficient to cover only about 30 percent of needed maintenance. In Benin road fund revenue is able to address only the maintenance needs of the main network. In Tanzania road fund revenue meets only 20-30 percent of maintenance needs. Ethiopia is an exception to this general picture: its road fund is able to address about 80 percent of assessed maintenance needs. In all countries maintenance requirements are greater if holding maintenance is performed to keep roads in fair condition while they await more thorough maintenance or to keep them passable while they await rehabilitation.

In contrast, Uganda, which has not created a road fund, has consistently met most of its maintenance budget requirements as well as counterpart funding needs through its normal budget process. It has committed more resources for maintenance per kilometer of road than any of its "securely funded" neighbors. It has also made explicit commitments to sustain maintenance funding, as well as the salaries and employment conditions offered by executing agencies, after the main donor financing ends.

\section{Disbursement}

Disbursement to executing agencies has been a serious problem. In 1998 only 55 percent of planned funds were disbursed in Benin, and in 1999 only 30 percent were disbursed in Zambia. In Ethiopia less than 40 percent of the road fund was disbursed in 1999-2000; the rest was invested in treasury bills. Ghana has been the most successful in this regard, disbursing more than 90 percent of allocated funds in 1998-99.

To some extent these poor outcomes have been the result of overly optimistic planning by the road boards, whose ability to plan far outstrips executing agencies' capacity to perform. But it appears that all the boards are learning from this experience. For example, Benin improved its disbursement share to 95 percent in 1999.

Disbursement performance differs significantly by type of road, with rural roads having low disbursement rates, usually less than half of those for main highways and urban roads. Several factors contribute to this pattern. The first is poor executing 
capacity in rural areas. The second is political pressure to maintain roads in capital cities. For example, Zambia's government emphasize rehabilitating roads in Lusaka during the early years of the road fund. Similarly, in Malawi half of the road fund's allocations in 1999 went to the cities of Lilongwe and Blantyre, with half of that used for rehabilitation. The third factor is the weak representation of rural road interests on most road boards.

\section{Capacity of Local Contractors}

Road funds appear to have helped insulate road maintenance contracting and payment arrangements from financial uncertainties. As a result work programming has improved, contracting has increased, and domestic contractors have grown, increasing efficiency. In Ghana and Zambia almost 90 percent of road maintenance is contracted out. In Ethiopia road maintenance continues to be performed using force account, but the Roads Authority is trying to increase its effectiveness by establishing commercial operations in maintenance districts. It is also jointly implementing performance contracts with the Road Fund Authority as a prelude to introducing contracting for maintenance works. In any case, Ethiopia's spending on road maintenance has more than doubled since 1996.

More reliable funding has had a dramatic effect on private sector contracting capacity and capability. In Zambia the number of local contractors jumped from 4 in 1994 to 450 in 1999, and local consultancy firms from 6 to 20 during the same period. In Benin 40 percent of maintenance was carried out using force account in 1998, down from 47 percent in 1997. Still, there is considerable scope for improving the capacity of local contractors in all the countries examined. In fact, one of the main constraints to efficient use of road fund resources remains the lack of sufficient local capacity for road maintenance.

\section{Operational Efficiency}

Better contract management and disbursement arrangements have reduced road maintenance costs by 10-20 percent in Ethiopia, Ghana, and Zambia. Zambia has also introduced a community-initiated cost-sharing scheme for road improvements.

Although these encouraging trends represent a significant departure from the past, evaluations of maintenance performed in Kenya and Zambia in 2000 reveal a number of shortcomings - mainly due to limited local capacity, technical constraints, and an inability to manage contractual arrangements. In Kenya funds have been allocated to roads of low economic priority and in some cases without compliance with contractual arrangements. The absence of a fully functional maintenance management system makes it difficult to ensure that the maintenance budget is allocated correctly, despite an adequate supply of small contractors to undertake minor works. 


\section{Condition of the Road Network}

Without detailed time-series data on road conditions, it is difficult to establish with precision what has been happening to the quality of the road networks in the countries reviewed. Moreover, most road funds were introduced when donor-financed rehabilitation programs were under way, and aggregate statistics cannot distinguish the separate effects on road conditions of the maintenance and rehabilitation programs. Even so, periodic data on road networks show the most promising picture in many years.

In Zambia road reforms have substantially improved the quality of the road network, and a sound strategy is in place to reverse the deterioration and neglect of recent decades. In Ethiopia the share of main roads in good condition increased from 15 percent in 1996 to 25 percent in 1999, whereas in Ghana the proportion of good roads increased from 21 percent in 1997 to 30 percent in 1999.

The picture is not all rosy. Although main and urban roads have improved, feeder and rural roads continue to deteriorate in some countries. This disparity partly reflects poor planning and programming and partly inadequate capacity in regional administrations. Years of neglect have limited the capacity of road agencies to perform maintenance-a deficiency most apparent in agencies responsible for rural and feeder roads.

\section{Conclusion}

It may seem premature to pass judgment on second-generation road funds. But some interesting patterns have emerged that are relevant to traditional debates on this topic. First, boards have had limited power to collect and allocate resources to road maintenance. Most road funds are still not able to fully fund their desired levels of maintenance because of residual ministerial control over the level of the fuel levy. Moreover, many road funds have trouble disbursing funds because of the low absorptive capacity of domestic maintenance industries.

Second, in some countries implementation of road works has become more efficient, reflecting more secure funding arrangements and increased use of private contractors. Thus revenue raising through road funds should match absorptive capacity rather than identified maintenance needs. This approach does not require full funding for desired programs but merely sufficient funding to maintain work programs and make payments in a timely fashion.

Third, improvements in the execution of road works will likely lag reforms in their financing, planning, and monitoring. But better execution will also depend on governments' willingness to take reforms beyond establishing a road fund.

To ensure continued improvements in road maintenance, governments must facilitate a more businesslike approach to it and give it a high priority in budget allocations. As Uganda's experience shows, it is possible to improve the execution of road 
works without creating a second-generation road fund-but only if existing structures adopt many of the procedures and processes associated with new road funds (separating implementation from financial control, improving managerial procedures, increasing private sector contracting, and so on). Thus better performance is surprisingly independent of institutional structures or resource allocation mechanisms but highly dependent on some critical aspects of process. The creation of a second-generation road fund has been as much an indicator of a country's willingness to change its approach as an essential mechanism for efficient maintenance.

In that light consider again the Gwilliam and Shalizi (1999) propositions offered at the start of this article. They argued that second-generation road funds should be viewed as an interim step toward either fully commercialized road maintenance or good governance in the public sector and that in deciding whether to create (or retain) a fund, decisionmakers should estimate its effects on resource allocation, operational efficiency, and rent seeking. The implication of their argument was that the funds being established should have a limited lifespan.

The authors were clearly driven to that conclusion by their recognition of the validity of both the macroeconomic desirability of fiscal flexibility and the microeconomic argument for reformed processes to improve road performance. But the history of the argument appeared to offer no compromise. To finesse their arguments for earmarking, the proponents of road funds had constructed an edifice in which part of a fuel tax was renamed a user charge, and in support of that device gave its determination the status of an internal business decision in what could be seen as a road users' cooperative. Although macroeconomists might not be fooled by this finesse, their fears could perhaps be appeased by the imposition of sunset clauses on new road funds.

Practicality has wished a plague on both houses. A weaker form of the secondgeneration road fund has emerged, stripped of the full commercial freedom for a user-dominated board to set its revenue. In addition, ministries of finance have been forced to recognize the advantages of most of the process changes brought by secondgeneration road funds-without yielding their ultimate control over taxation or spending responsibilities for an important public good. The outcome has often been surprisingly favorable in terms of efficient spending on maintenance, regardless of whether that spending met the aggregate assessed need. Commercialization of road maintenance and fiscal flexibility have turned out to be complements rather than alternatives.

This experience suggests a rather different conclusion from that reached by Gwilliam and Shalizi. Certainly the road funds should be kept under review. But there is no need for the Damoclean sword of a sunset provision, which might only undermine confidence in the important process changes that have been brought about. Rather, the reviews should be embodied in strong technical and efficiency audits, both of the road funds and of the implementing agencies, whether in the private or public sector. 


\section{Note}

Ken Gwilliam was formerly economic adviser in the Transport and Urban Development Department at the World Bank. His e-mail address is kengwilliam@yahoo.com. Ajay Kumar is consultant economist in the Africa Transport Department at the World Bank. His e-mail address is akumar3@worldbank.org. This article is based on work carried out under the Road Management Initiative, which was created in 1988 to increase awareness about the importance of road maintenance and support country programs that take a sustainable, long-term approach to managing and financing roads. Task managers involved in country operations were a major source of information for this article, and the authors are indebted to many who generously shared their experiences_-particularly Anil Bhandari, Stephen Brushett, Pedro Geraldes, Yitzhak Kamhi, John Riverson, Simon Thomas, and Thor Wetteland. The authors are also grateful for the valuable information provided by many people working in the road agencies, local governments, and transport associations of the countries studied.

\section{References}

Gwilliam, K. M., and Z. Shalizi. 1999. "Road Funds, User Charges and Taxes.” World Bank Research Observer 14(2):159-85.

Harral, C., and A. Faiz. 1988. Road Deterioration in Developing Countries: Causes and Remedies. A World Bank Policy Study. Washington, D.C.: World Bank.

Heggie, I. G. 1995. Management and Financing of Roads: An Agenda for Reforms. World Bank Technical Paper 275. Africa Technical Series. Washington, D.C.

Kumar, A. 2000a. "Assessment of Selected Road Funds in Africa." Sub-Saharan Africa Transport Policy Program Working Paper 51. World Bank, Africa Region, Washington, D.C.

—. 2000b. "Implementing Second-Generation Road Funds: Lessons Learned.” Africa Technical Note/Road Management Initiative Note 31. World Bank, Africa Region, Washington, D.C.

— 2002a. "A Contrasting Approach to Road Sector Reforms: The Experience of Uganda.” SubSaharan Africa Transport Policy Program Discussion Paper 1. World Bank, Africa Region, Washington, D.C.

—. 2002b. "A Review of Road Sector Reforms in Tanzania." Sub-Saharan Africa Transport Policy Program Discussion Paper 2. World Bank, Africa Region, Washington, D.C.

Nyangaga, F. N. 2001. "Reforming Road Management in Sub-Saharan Africa.” Africa Technical Note/ Road Management Initiative Note 32. World Bank, Africa Region, Washington, D.C.

Potter, B. 1997. "Dedicated Road Funds: A Preliminary View on a World Bank Initiative.” Working Paper 97/7. International Monetary Fund, Washington, D.C. 